\title{
NUTRITIONAL EVALUATION OF BAMBARA GROUNDNUT (Vigna subterranea (L.) Verdc) FROM LAPAI, NIGERIA
}

\author{
Musah M. ${ }^{*}$, Azeh Y. ${ }^{1}$, Mathew J.T. ${ }^{1}$, Nwakife C.N. ${ }^{2}$, Mohammed A.I. ${ }^{1}$ and Saidu F. ${ }^{1}$ \\ ${ }^{1}$ Department of Chemistry, Ibrahim Badamasi Babangida University, Lapai, Nigeria \\ ${ }^{2}$ Department of Chemistry, Federal University of Technology, Minna, Nigeria \\ *Corresponding email: mkkoro22@gmail.com
}

\section{Cite this article:}

Musah M., Azeh Y., Mathew J.T., Nwakife C.N.,

Mohammed A.I., Saidu F. (2021), Nutritional Evaluation of Bambara Groundnut (Vigna subterranea (L.) Verdc) From Lapai, Nigeria. African Journal of Agriculture and Food Science 4(4), 32-39. DOI:

10.52589/AJAFS_SQI5U7CN

\section{Manuscript History}

Received: 12 Nov 2021

Accepted: 29 Nov 2021

Published: 4 Dec 2021

Copyright $\odot 2020$ The Author(s). This is an Open Access article distributed under the terms of Creative Commons AttributionNonCommercial-NoDerivatives 4.0 International (CC BY-NC-ND 4.0 ), which permits anyone to share, use, reproduce and redistribute in any medium, provided the original author and source are credited.
ABSTRACT: The nutritional constituents of seeds of Bambara groundnut (Vigna subterranean) were analyzed for their nutritional compositions using standard analytical methods. Results of proximate analysis obtained were moisture content $(9.20 \pm 0.12 \%)$, ash $(3.40 \pm 0.09 \%)$, carbohydrate $(21.10 \pm 0.05$ $\%)$, crude fibre $(4.60 \pm 0.07 \%)$ and calorific value $(185.79 \pm 0.03$ kcal/100 g). Mean concentrations of mineral elements were the order: zinc $(139.00 \pm 0.04 \mathrm{mg} / 100 \mathrm{~g})>$ potassium $(31.50 \pm 0.12$ $\mathrm{mg} / 100 \mathrm{~g})>$ copper $(30.00 \pm 0.01 \mathrm{mg} / 100 \mathrm{~g})>$ phosphorus $(17.40 \pm 0.11 \mathrm{mg} / 100 \mathrm{~g})>$ magnesium $(3.90 \pm 0.07 \mathrm{mg} / 100 \mathrm{~g})>$ calcium $(3.50 \pm 0.17 \mathrm{mg} / 100 \mathrm{~g})>$ sodium $(0.11 \pm 0.03 \mathrm{mg} / 100 \mathrm{~g})$ > iron $(0.10 \pm 0.01 \mathrm{mg} / 100 \mathrm{~g})$. Measured values for bulk density, water absorption capacity, oil absorption capacity, foaming capacity and foaming stability were $0.85 \pm 0.07 \mathrm{~g} / \mathrm{cm}^{3}, 1.65 \pm 0.13$ $\%, 0.70 \pm 0.03 \%, 16.00 \pm 0.12 \%$ and $7.50 \pm 0.22 \%$ respectively. The amino acid profile revealed that glutamic acid had the highest value $(12.56 \mathrm{~g} / 100 \mathrm{~g})$ while tryptophan had the lowest concentration $(0.87 \mathrm{~g} / 100 \mathrm{~g})$. Results obtained indicate that the consumption of $V$. subterranean can contribute to the nutritional requirements of the body.

KEYWORDS: Vigna Subterranean, Nutritional, Carbohydrate, Minerals, Amino Acids. 


\section{INTRODUCTION}

The last decade has witnessed increased food shortage and hunger in Nigeria (especially in the North) occasioned by grave insecurity, climate change, cost of fertilizer, communal conflicts, increase in population and changes in dietary pattern of the populace. These situations have heightened the competition for conventional foodstuff needed for adequate supply of nutrients required for good health and development of the body (Musah et al., 2020). Lack of sufficient food supply with necessary nutrients could lead to malnutrition especially in young children. To mitigate the effect of nutrient inadequacy and improve sustainable food security, it is important to explore affordable and readily available plantbased food such as fruits, vegetables, roots and tubers, nuts and seeds for their nutritive values. One such plant-based food is the Bambara groundnut (Vigna subterranean (L.) Verdc).

Bambara groundnut (V. subterranea (L.) Verdc) is a legume indigenous to Africa; it is cultivated in semi-arid regions of Africa. It is associated with small-scale, subsistence farming and relatively unpopular compared with major cash crops like rice, yam, beans and cocoa. V. subterranea is a member of the family Fabaceae; it is an annual, creeping legume with glabrous, trifoliate leaves. It has a deep taproot surrounded by lateral profuse roots bearing $\mathrm{N}$-fixing nodules. It ripens its pods underground like the peanut but gives superior yield to the peanut in poor soil. Seeds of $V$. subterranea are round, smooth and hard when dry, used in different forms as food for humans while the leaves are fed to ruminants. The seeds are converted into different forms, milled into powder and paste for making cake.

The seeds can be consumed in different forms either in the immature green state or mature form. But at maturity, the seeds become very hard and therefore require boiling before any specific preparation can be carried out. However, it is common knowledge that legume seeds generally require a long cooking time for tenderization (Omoikhoje, 2008). The nut can be eaten raw when immature because it is soft and pleasant. Bambara groundnut is also consumed as a salt-boiled snack food beside maize and cowpea (Iyayi et al., 2005). The extracts from plant nuts, particularly protein extracts, can be used directly in cosmetic formulations and they provide specific properties and notable particular effects (Aburjai \& Natsheh, 2003).

The present study will help to authenticate the already existing database for the study of plant resources among the rural dwellers of Niger State, and probe into their likely nutritional potential to ascertain if they could help to complement the nutritional needs from other food sources.

\section{MATERIALS AND METHODS}

\section{Sample collection}

Mature and dried Vigna subterranean (L.) Verdc seeds used for this research were obtained from Sabon Kasuwa market in Minna, Nigeria. They were dried under the sun and carefully removed from their hulls, ground into powder using mortar and pestle and stored in a plastic container ready for analysis. 


\section{Proximate Composition}

Moisture content was determined by drying $5 \mathrm{~g}$ of the powdered sample to constant weight in an oven at $105{ }^{\circ} \mathrm{C}$. The difference in weight before and after drying was recorded as the moisture content of the seed (AOAC, 2006). Ash content was quantified according to the method described by Ceirwyn (1998), which involved dry ashing in a muffle furnace at 600 ${ }^{\circ} \mathrm{C}$ until grayish white ash was obtained. Crude lipid content was determined using soxhlet apparatus and n-hexane as solvent, according to the AOAC (2006) method. Crude protein of the sample was determined by multiplying the value obtained from Kjeldahl's nitrogen analysis by a protein factor of 6.25 (AOAC, 2006). Available carbohydrate was estimated by difference where the sum of the percentage ash, crude lipid, crude protein, and crude fiber was subtracted from $100 \%$ as shown in equation 1 (AOAC, 2006). Calorific value was calculated using expression described in equation 1 by Asibey-Berko and Taye (1999).

Available Carbohydrate $(\%)=100-(\%$ ash $+\%$ protein $+\%$ lipid $\%$ fibre $)$

Energy $($ kcal $/ 100 \mathrm{~g})=($ crude protein $\times 2.44)+($ crude lipid $x 8.37)+$ (available carbohydrate $x$ 3.57)

\section{Determination of Amino Acids}

The amino acids profiles of the seed sample was determined using methods described by Barakat et al. (2017) with modifications as described in AOAC (2006). The sample was defatted, hydrolysed, evaporated in a rotary evaporator and loaded into the Technicon sequential multi-sample Amino Acid Analyser (TSM).

\section{Mineral Quantification}

Oven dried powdered sample (6 g) was put into a dry crucible and ignited in a muffle furnace at $600{ }^{\circ} \mathrm{C}$ until greyish white ash was obtained. The sample was removed and cooled in a desiccator. $5 \mathrm{~cm}^{3}$ of $1.0 \mathrm{~mol} \mathrm{dm}{ }^{-3} \mathrm{HNO}_{3}$ was added and the sample was evaporated to dryness on a steam bath and reheated in a muffle furnace until the formation of greyish white ash was observed. The ash was cooled in a desiccator and $10 \mathrm{~cm}^{3}$ of $1.0 \mathrm{~mol} \mathrm{dm} \mathrm{dm}^{-3} \mathrm{HCl}$ was added and filtered into a $100 \mathrm{~cm}^{3}$ volumetric flask. The concentrations of $\mathrm{Cu}, \mathrm{Fe}, \mathrm{Mg}, \mathrm{Zn}$ and $\mathrm{Ca}$ were determined using Atomic Absorption Spectrophotometer (AAS Model SP9) while Na and K were evaluated using flame photometer. Phosphorus concentration was quantified using the Jenway 6100 spectrophotometer at $420 \mathrm{~nm}$ (Ceirwyn, 1998).

\section{Functional Properties}

Bulk density was determined by gently filling a $10 \mathrm{~cm}^{3}$ graduated measuring cylinder with the sample and its bottom was gently tabbed until the volume of the sample stopped decreasing (Yoshiyuki \& Yukata, 2003). Foam capacity and stability were determined according to the method described by Abbey and Ibeh (2006) while water and oil absorptions capacities were determined using the methods in Musah et al. (2021). 


\section{RESULTS AND DISCUSSION}

\section{Proximate Composition}

The results of the proximate composition in Table 1 showed high moisture content in $V$. subterranea seeds (49.20\%). The value was found to be higher than $2.86 \pm 0.22$ obtained for $V$. subterranea seeds from Maikunkele market (Mathew et al., 2014). The high moisture content of these seeds indicates that they will be susceptible to microbial growth and will not have a long shelf life (Ndamitso et al., 2014). The carbohydrate content $(44.10 \pm 0.05 \%)$ obtained was lower than the $58.09 \%$ and $66.45 \%$ reported for Cola acuminate and Cola nitida respectively (Dewole et al., 2013). Dietary carbohydrates supply the bulk of calories in an average diet.

Table 1: Proximate composition of Bambara nuts (Vigna subterranea) (\% Dry weight)

\begin{tabular}{ll}
\hline Parameter & Content \\
\hline Moisture & $49.20 \pm 0.12$ \\
Ash & $3.40 \pm 0.09$ \\
Crude fibre & $4.60 \pm 0.07$ \\
Crude protein & $19.20 \pm 0.11$ \\
Crude lipid & $7.60 \pm 0.21$ \\
Available Carbohydrate & $44.10 \pm 0.05$ \\
Calorific value $(\mathrm{kcal} / 100 \mathrm{~g})$ & $185.79 \pm 0.03$ \\
\hline
\end{tabular}

Values are means of triplicate determination \pm standard deviations. Calculated energy value was $185.79 \pm 0.03 \mathrm{kCal} 100 \mathrm{~g}^{-1}$. This value was higher than the $155.04 \pm 1.60 \mathrm{kCal} 100 \mathrm{~g}^{-1}$ reported for $V$. subterranea seeds (Mathew et al., 2014). The results showed a moderately high protein content of $19.20 \pm 0.11 \%$, although the value was low compared to the $32.40 \pm 0.02 \%$ reported for Bambara groundnut by Nwodo and Nwinyi (2012). The protein content of the seeds revealed that they could be considered a good source of protein for humans. The fat content value was relatively high $(7.60 \%)$ while total ash content of the seeds was low (3.84\%). These values were within the range of 6-8 \% ash content reported for $V$. subterranea seeds (Ojimelukwe, 1999). The low ash content of $V$. subterranea seeds indicates the low total level of inorganic components in the sample. It has been reported that a diet providing 1-2\% of its caloric energy as fat is sufficient for humans (Shaba et al., 2015). Excess fat consumption may contribute to certain cardiovascular disorders.

\section{Mineral Composition}

Table 2 presents the result of mineral composition of $V$. subterranea seeds. The results revealed that potassium and phosphorus were the most abundant minerals present in the seeds. Similarly, potassium and phosphorus were reported as the most abundant minerals in V. subterranea seeds (Belewu et al., 2008). Phosphorus helps in bone growth, proper kidney function and cell growth. Potassium also plays a role in maintaining the body's acid-alkaline balance (Ndamitso et al., 2017). Mathew et al. (2014), in a related study, reported high potassium content of $122.91 \pm 1.02$ for $V$. subterranea obtained from Kure Market. The results showed the low contents of calcium $(3.50 \pm 0.17 \mathrm{mg} / 100 \mathrm{~g})$ and magnesium $(3.90 \pm 0.07$ $\mathrm{mg} / 100 \mathrm{~g}$ ), whereas Belewu et al. (2008) recorded these minerals in relatively high concentrations in $V$. subterranea seeds. 
Table 2: Mineral composition of Bambara nut (Vigna subterranea)

\begin{tabular}{ll}
\hline Mineral & Concentration $(\mathbf{m g} / \mathbf{1 0 0} \mathbf{g})$ \\
\hline Sodium & $0.10 \pm 0.09$ \\
Potassium & $31.50 \pm 0.12$ \\
Calcium & $3.50 \pm 0.17$ \\
Iron & $0.10 \pm 0.01$ \\
Zinc & $139.00 \pm 0.04$ \\
Phosphorous & $17.40 \pm 0.11$ \\
Magnesium & $3.90 \pm 0.07$ \\
Copper & $30.00 \pm 0.01$ \\
\hline
\end{tabular}

Values are means of triplicate determination \pm standard deviations. The daily requirement of sodium for males and females between 9 and 50 years is $1500 \mathrm{mg}$, which has been recommended as an adequate intake, while after the age of 59 years, $1300 \mathrm{mg}$ has been considered as adequate by the U.S. Food and Drug Administration (Carol, 2011). As observed in the present study, iron and sodium were detected in very low concentrations. Therefore, suggesting consumption of the seeds could be effective and useful for people with high blood pressure (Ogbuagu et al., 2011; Dzomeku et al., 2006).

\section{Amino Acid Profile}

The results of the amino acids profile of the $V$. subterranea seed are shown in Table 3 . The result revealed the presence of essential and non-essential amino acids in the study seeds. The total essential amino acid was $57.60 \mathrm{~g} / 100 \mathrm{~g}$, while total non-essential amino acid was 42.40 $\mathrm{g} / 100 \mathrm{~g}$. The value of total essential amino acid was higher than $27.90 \mathrm{~g} / 100 \mathrm{~g}$, though in the case of total non-essential amino acid, the value was lower than $51.11 \mathrm{~g} / 100 \mathrm{mg}$ reported for $X$. americana seed by Tanko et al. (2017).

Table 3: Amino acid profile of Bambara nuts (Vigna subterranea)

\begin{tabular}{ll}
\hline Amino Acid & Concentration $\mathbf{( g / 1 0 0 ~ g )}$ \\
\hline *Leucine & 7.12 \\
*Lysine & 6.26 \\
*Isoleucine & 4.06 \\
*Phenylalanine & 4.43 \\
*Tryptophan & 0.87 \\
*Valine & 4.29 \\
*Methionine & 1.33 \\
*Arginine & 6.79 \\
*Histidine & 2.55 \\
*Threonine & 4.16 \\
Proline & 3.14 \\
Tyrosine & 3.09 \\
Cystine & 1.33 \\
Alanine & 3.71 \\
Glutamic acid & 12.56 \\
Glycine & 3.70 \\
\hline
\end{tabular}




\begin{tabular}{ll}
\hline Serine & 3.29 \\
Aspartic acid & 9.67 \\
Total amino acid (TAA) & 72.68 \\
Total Essential Amino Acid (TEAA) & 41.86 \\
Total Non Essential Amino Acid (TNEAA) & 30.82 \\
$\%$ TEAA & 57.60 \\
$\%$ TNEAA & 42.40 \\
\hline
\end{tabular}

$*=$ Essential amino acid (EAA)

The minimum amino acid intake of $1.5 \mathrm{~g} / \mathrm{kg} / \mathrm{day}$ is reported to be necessary in preventing negative nitrogen balance, a minimum amino acid intake of $1.0 \mathrm{~g} / \mathrm{kg} / \mathrm{day}$ is recommended to avoid a negative nitrogen balance, and an intake higher than $2.5 \mathrm{~g} / \mathrm{kg} /$ day is not advisable (ESPGHAN, 1987).

\section{Functional Properties}

The functional properties of Vigna subterranea are presented in Table 4. The water absorption capacity (WAC) content was $1.65 \pm 0.13 \%$ which is lower than the $201.7 \%$ obtained for raw groundnut seeds reported by Mustapha et al., (2015). The high water absorption capacity may be due to the high polar amino acid residues of raw groundnut proteins having strong affinity for water molecules (Narayana \& Narasinga, 1985).

Table 4: Functional Properties of Bambara Nuts (Vigna subterranea)

\begin{tabular}{ll}
\hline Parameter & Value \\
\hline Water Absorption Capacity $(\%)$ & $1.65 \pm 0.13$ \\
Oil Absorption Capacity $(\%)$ & $0.70 \pm 0.03$ \\
Bulk Density $\left(\mathrm{g} / \mathrm{cm}^{3}\right)$ & $0.85 \pm 0.07$ \\
Foaming Capacity $(\%)$ & $16.00 \pm 0.12$ \\
Foaming Stability $(\%)$ & $7.50 \pm 0.22$ \\
\hline
\end{tabular}

Values are means of triplicate determination \pm standard deviations. The foam stability of the study sample is $7.50 \pm 0.22 \%$. This was high compared to $5.88 \pm 0.41 \%$ reported for Bombax buonopozense Calyx by Musah et al. (2021). Foam stability is dependent on protein content and environmental temperature. The higher the protein content, the higher the foam stability (Ocloo et al., 2012). Bulk density (BD) was $0.85 \pm 0.07 \mathrm{~g} / \mathrm{cm}^{3}$. This value is higher than the value of $0.52 \pm 0.710 .24 \pm 0.04 \mathrm{~g} / \mathrm{cm}^{3}$ reported for Bombax buonopozense Calyx (Musah et al., 2021). Higher bulk density is advantageous since it helps to reduce the paste thickness which is an essential factor in child feeding (Mustapha et al., 2015). However, the groundnut $V$. subterranea seed could be used as a food supplement for children. 


\section{CONCLUSION}

The nutritional potential of $V$. subterranea seeds is linked to the presence of proximate amino acids and essential minerals such as calcium, magnesium, potassium, sodium, iron, and manganese. The low anti-nutrient content of these seeds shows that it could be exploited as a good dietary supplement for both human and animal feed formulation. As a good source of nutrients and non-nutrients, the crops can be recommended for inclusion in the food system of Nigeria to improve human health care. The physicochemical contents attributed to the study sample will enable the wider use and application of the crop in numerous food products, for instance, as alternative flour, modified starch, or protein isolate.

\section{REFERENCES}

Abbey, B. W. \& Ibeh, G. O. (2006). Functional properties of raw and heat processed cowpea (Vigna unguiculata) flour. Journal of Food Science, 53, 6, pp. 1775-1777.

Aburjai, T. and Natsheh, F. M. (2003). Plants used in cosmetics. Phytotherapy Research, 17, 987-1000

AOAC (2006). Official methods of association of official analytical chemist, association of official analytical chemists inc. Alington, Washington DC., USA.

Asibey-Berko, E. \& Tayie, F.A.K. (1999). Proximate analysis of some underutilized Ghanian vegetables. Ghana Journal of Science, 39,91-92.

Barakat, H. Khalifa, I. Ghazal, G. A. Shams, A. \& Denev, P. N. (2017). Chemical composition and nutritional value of seeds from quinoa accessions, cultivated in Egypt. Bulgarian Chemical Communication, 49,231-238.

Belewu, M. A., Fagbemi, T., Dosumu, O. O. \& Adeniyi, M. O. (2008). Physico-chemical and anti-nutritional properties of some lesser known tree and leguminous seeds. Int. J. Agric. Res., 3(3),237-242.

Carol, L. (2011). Daily requirement for sodium, fat, fibre, calcium and iron. American journal of Nutrition, 33(3),20-67.

Ceirwyn, S. J. (1998). Analytical Chemistry of food. Chapman and Hall publisher, London, pp. 75-77.

Dewole, E.A., Dewumi, D.F.A., Alabi, J.Y.T. \& Adegoke, A. (2013). Proximate and Phytochemical of Cola nitida and Cola acuminata. Pakistan Journal of Biological Sciences, 16, 1593-1596.

Dzomeku, B. M., Bam, R. K., Abu-Kwarteng, E. E. \& Ankomah, A. A. (2006). Comparative study on the nutritional values of FHIA-21 (TetraploidHybrid) and 'apem' (Triploid French plantain) in Ghana. Journal of Plant Science, 181-191.

ESPGHAN (1987). European Society of Paediatric Gastroenterology and Nutrition. Nutrition and Feeding of Preterm Infants. Acta. Paediatric Scand Supply, 336, 1-4.

Iyayi, E. A., Ogunsola, O. \& Nair, V. (2005) Effects of sources of fibre and period of feeding on the performance, carcass measures, organ relative weight and meat quality in broilers. International Journal of Poultry Science, 4, 695-700.

Mathew, J. T., Adamu, A., Otori, A. A., Muhammed, S. S., Ibenome, A., Ahmed, S. B. \& Umar, M. M. (2014). Comparative Nutritional Values of Bambara Nut Obtained from Major Markets in Minna Metropolis, Niger State. Elixir Applied of Chemistry. 72, $25701-25703$. 
Musah M., Muhammad H. I., Mathew J. T., Azeh Y., Umar M. T. \& Goshie S. N. (2021). Proximate, Minerals and Functional Properties of Bombax buonopozense Calyx. Communication in Physical Sciences, 7(2), 126-133.

Musah, M., Ndamitso, M.M., Yerima, H., Mathew, J.T. and Iwachukwu, G.O. (2020). Nutritional assessment of Vigna unuiculata sub spp sesquipedalis seeds. Communication in Physical Science, 5(4),446-454.

Mustapha S., Mohammed U.M., Adeosun N.O., Mathew J. T., Muhammed S.S. \& Ibn-Aliyu A. (2015). Nutritional and Functional Characterization of Undecorticated Groundnut (Arachis hypogaea L.) Seeds from Bosso Market, Minna, Nigeria. American Journal of Food Science and Technology. 3(5), 126-131.

Narayana, K. \& Narasinga Rao, M. S, (1985). Functional properties of raw and heat processed winged bean (Psophocarpus tetragonolobus) flour. Journal of Food Science, 47, 1534-1538.

Ndamitso M. M., Mathew J. T., Ajai A. I., Shaba E. Y., Etsuyankpa B. M. \&Salihu A. B. (2014). Comparative Nutritional values of Selected Curcubit Seeds in Minna, Niger State, Nigeria. Journal of Applied Chemistry, 3, 26-28.

Ndamitso M. M., Mustapha S., Etsuyankpa M. B., Ajai A. I. and Mathew J. T. (2017). Evaluation of Chemical Composition of Acacia nilotica Seeds. FUW Trends in Science \& Technology Journal, 2(2), $927-931$.

Nwodo, S. N. \& Nwinyi, C. O. (2012). Proximate analysis of Sphenostylis stenocarpa and Voadzeia subterranean consumed in South-Eastern Nigeria. Journal of Agricultural Biotechnology and Sustainable Development, 4(1), 19-29.

Ocloo, F. C. K., Darfour, B., Wilson, D. D. \& Ofosu, D. O. (2012). Physical, proximate, functional and pasting properties of flour produced from gamma irradiated cowpea (Vigna unguiculata,L. Walp), Radiation Physics and Chemistry, 81, 450-457.

Ogbuagu, M. N., Odoemelam, S. A. \& Ano, A. O. (2011). Chemical composition of underutilized tropical African seed: Adenanthera pavonina. Journal of Chemical Society of Nigeria, 36(1) 23-28.

Ojimelukwe, P. C., Onweluzo, J.C. \& Okechukwu, E. (1999). Effects of infestation on the nutrient content and physiocochemical properties of two cowpea (Vigna unguiculata) varieties. Plant Foods for Human Nutrition 53,321-332.

Omoikhoje, S.O., 2008. Assessment of the nutritive value of bambara nut as influenced by cooking time. Livest. Res. Rural Dev., 20: 55.

Shaba E. Y., Ndamitso M. M., Mathew J. T., Etsunyakpa M. B., Tsado A. N. \& Muhammad S. S. (2015). Nutritional and anti-nutritional composition of date palm (Phoenix dactylifera L.) fruits sold in major markets of Minna Niger State, Nigeria. African Journal of Pure and Applied Chemistry, 9(8), 167-174.

Tanko E., ajai A. I., Lafiya-Araga R. A., Dauda B. E. N., Mathew J. T. \& Omosokpia J. (2017). Physico-chemical, Fatty Acid profile and Amino acid Composition of the Fruit pulp and Seeds of Ximennia americana L. (Tallow plum) Obtained in Niger State, Nigeria. International Journal of Food Chemistry, 1(2), 30-34.

Yoshiyuku, S. \& Yukata, K. (2003). Pyrolysis of plant, animal and human wastes: physical and chemical characterization of the pyrolytic product. Bioresource Technology, 90, 3, pp. 241-247. 